\title{
ON THE PRODUCTION AND SPECIFIC TREATMENT OF TYPHOID INFECTION IN ANIMALS.
}

\author{
By E. W. Ainley Walker, M.A., M.D. (Oxon.), Radeliffe Travelling \\ Fellow of the University of Oxford.
}

Most antityphoid sera which have been prepared have given no marked assistance in the treatment of disease in man; though some apparent cures have been recorded by Professor Tavel ${ }^{1}$ of Berne. More recently von $\mathrm{Jez}^{2}$ of Vienna has claimed to have obtained invariably good results with a tissue extract obtained from the organs of animals immunised against the Bacillus typhosus. And antityphoid sera may undoubtedly possess curative power for animals against typhoid infection, as has been shown by Funck, ${ }^{3}$ by Bokenham ${ }^{4}$ and by others.

In a previous paper ${ }^{5}$ the writer endeavoured to define the conditions for the production of an antityphoid serum of definite therapeutic value, and showed that the sera prepared in Berne were protective for guinea-pigs in proportion as the treatment of the horses used conformed to these conditions, which are in general a wide polyvalence and a higb degree of inmunisation against the living typhoid organisms. At the suggestion of Professor Tavel I proceeded recently, in continuation of this work, to examine the curative power of the most powerful of these sera on rabbits; at the same time comparing the results with those obtained in parallel experiments by treatment with a typhoid extract similar to that described by Jez, and exhibited by him with apparent success in cases of enteric fever in man.

This observer, starting from the theory put forward especially by Wassermann that the bodies concerned in protection against microbic infection are formed in the process of immunisation and are to some extent locked up in certain glands and tissues of the body, endeavoured to separate the substances in question from the organs of rabbits which had been rapidly immunised against the B. typhosus by grinding up the spleen, thymus, brain, and spinal cord, and bone-

\footnotetext{
I “Ueber das Typhus Serum," Schweizerisches Serum und Impf, -Institut, Ber., Mar. 1899.

"Wien. med. Wchnschr., 1899, Bd. xlix. S. 346.

3 "La Sérothérspie de Ia fièrre typhoide," Bruxelles, 1896.

Trans. Path. Soc. London, 1898, vol. xlix. p. 373.

'Journ. Path. and Bacteriol., Edinburgh snd London, 1901, vol. vi. p. 250. 25 -J. OF PATH.--rol, viL
} 
marrow, and extracting them by means of a particular solution. The extract thus obtained was administered by the mouth in cases of typhoid fever in man, and was used in eighteen such cases with uniformily good results, and von $\mathrm{Jez}$ believes that he has in it obtained a specific remedy for this disease. It was therefore of interest to determine whether such an extract is in any way superior to an iromune serum in protective action, or can add to such a serum any constituent of protective value. For unless the extract be distinctly superior to immune serum in its therapeutic action the continuous labour and the sacrifice of animals involved in its production, together with the relatively large amount required, - von Jez indicates about half a litre as the total dosage necessary for an ordinary case of typhoid fever,-preclude its use to any great extent, both on the ground of cost and from the difficulty of preparing it in quantity sufficient to meet the requirements of an ordinary epidemic.

It was accordingly decided to make the following series of experiments on rabbits:-

1. Infection with typhoid bacilli and treatment with Jez extract.

$\begin{array}{llll}2 . & \text { " } & \text { " } & \text { immune serum. } \\ \text { which the extracting solution of von Jez was replaced by immune serum. }\end{array}$

The experinents in Series 1 were undertaken by Dr. Glücksmann, assistant to Professor Tavel, while those in Series 2 and 3 I carried out.

Jez extract and the serum extract were prepared as follows:- In each case five similar rabbits of $2 \mathrm{kgrms}$. weight or over were employed and treated as below, the M.L.D. being calculated for a rabbit of $2 \mathrm{kgrmas}$.

DAY 1. Intraperitoneal injection of 0.05 per cent. M.L.D. of a 48 -hour old

2. Nil.

3. Intraperitoneal " $0.1 \quad, \quad$,

4. Nil.

5. Intraperitoneal " $0.5 \quad$,

6. Nil.

7. Intraperitoneal $\quad 1.10$

8. Nil.

9. Intraperitoneal,$\quad 2 \cdot 0$

10. Nil.

,11. Intraperitoneal,$\quad 50$

"12. Nil.

On the thirteenth day the animals were killed, the spleen, thymus, adrenals, brain, and spinal cord removed and weighed, and ground up in a mortar, and the limb-bones cleaned and chopped in pieces. The whole was then extracted with a mass of fluid equal to ten times the weight of the groundup organs. In the case of $J_{\mathrm{e} z}$ extract the fluid used consisted of the following solution :-

Pepsin

Sodium chloride .

Glycerin

Alcohol

Distilled water
2 grms.

6 " 30 drops.

100 grms.

$900 "$ 
And the extraction was carried on for twenty-four hours in the hot chamber, after which the fluid was separated, filtered, and set aside for use. For the preparation of the serum extract a corresponding volume of immune serum was used instead of Jez solution, and the extraction continued in the ice-chest for forty-eight hours, after which the fluid was rapidly separated, filtered, and again rendered sterile by filtration through a Chamberland bougie.

Since it was intended to examine not merely the protective but also the curative power of the preparations concerned, it was desirable to produce if possible a definite and continued illness in the animals employed. In animal experiments with protective sera it usually happens that the reaction is completed in the course of a few days at most, death or recovery rapidly ensuing according to the degree of the infection and the amount of the protective agent given. For typhoid at any rate, such phenomena are in no way comparable to the disease as it appears in man, and the results obtained with animals from the use of immune serum are accordingly not conclusive for a protective action against typhoid fever proper. It was, however, found possible to give rise to a continued fever in the rabbit by the exhibition of a number of successive intraperitoneal inoculations of the infecting organism, each accompanied by a subcutaneous injection of protective serum in amount sufficient to preserve life but insufficient for complete protection. This is well illustrated in the following experiment, which may here be quoted:-

Four young rabbits were taken and injected intraperitoneally on four successive days with the doses given below of living typhoid culture.

DAY 1. One half of a 48-hour old agar culture.

2. One 24-hour agar culture

3. One 48-hour " "

4. One 48-hour " "

Rabbit 1 received no other treatment.

$" \quad 2$ received 5 c.c. of antityphoid serum subcutaneously two days before the first infecting injection.

" 3 received 5 c.c. of antityphoid serum subcutaneously with each infecting injection.

, 4 received 5 c.c. of antityphoid serum mixed and injected intraperitoneally with each infecting injection.

The course of the experiment is shown in the subjoined table of weights and temperatures, the days on which the four infecting injections were given being marked by stars (Table I.).

It appears from this that while Rabbit 1 died after the third injection of the $B$. typhosus, Rabbit 4 was completely protected by the immune serum, and Rabbits 2 and 3 acquired a definite illness which was still in progress at the last observation on the twenty-first day from first infection. Hence it is possible to produce a condition of continuing disease by the method employed either with Rabbit 2 or Rabbit 3. For certain reasons, which need not enter into this discussion, the latter appeared preferable, and was accordingly made use of in the present observations. 
TABLE I.

\begin{tabular}{|c|c|c|c|c|c|c|c|c|}
\hline \multirow[b]{2}{*}{ Day. } & \multicolumn{2}{|c|}{ RABBIT 1 . } & \multicolumn{2}{|c|}{ RABBIT 2.} & \multicolumn{2}{|c|}{ RABBit 3.} & \multicolumn{2}{|c|}{ RABBIT 4.} \\
\hline & $\begin{array}{l}\text { Weight in } \\
\text { Grms. }\end{array}$ & $\begin{array}{l}\text { Tempera } \\
\text { ture. }\end{array}$ & $\begin{array}{c}\text { Weight in } \\
\text { Grms. }\end{array}$ & $\begin{array}{l}\text { Tempera- } \\
\text { ture. }\end{array}$ & $\begin{array}{l}\text { Weight in } \\
\text { Grme. }\end{array}$ & $\begin{array}{l}\text { Tempera. } \\
\text { ture. }\end{array}$ & $\begin{array}{c}\text { Weight in } \\
\text { Orms. }\end{array}$ & $\begin{array}{l}\text { Tempera- } \\
\text { ture. }\end{array}$ \\
\hline 1 & 1670 & $37 \cdot 7$ & 1390 & $37 \cdot 7$ & 1730 & $37 \cdot 7$ & 1310 & $37 \cdot 5$ \\
\hline $3^{*}$ & 1680 & $37 \cdot 8$ & 1400 & $37 \cdot 5$ & 1730 & $37 \cdot 8$ & 1370 & $37 \cdot 8$ \\
\hline $4^{*}$ & 1630 & $38 \cdot 6$ & 1320 & $38 \cdot 3$ & 1670 & $38 \cdot 3$ & 1370 & $37 \cdot 7$ \\
\hline $5^{*}$ & 1510 & $37 \cdot 0$ & 1260 & $38 \cdot 5$ & 1560 & $38 \cdot 7$ & 1310 & $38 \cdot 4$ \\
\hline $6^{*}$ & 1460 & dead & 1210 & $38 \cdot 6$ & 1530 & $38 \cdot 3$ & 1330 & $39 \cdot 3$ \\
\hline 7 & $\ldots$ & $\ldots$ & 1170 & $37 \cdot 3$ & 1480 & $39 \cdot 0$ & 1430 & $38 \cdot 3$ \\
\hline 8 & $\ldots$ & $\ldots$ & 1130 & $37 \cdot 7$ & 1450 & $38 \cdot 9$ & 1430 & $39 \cdot 1$ \\
\hline 9 & $\ldots$ & $\ldots$ & 1080 & $38 \cdot 5$ & 1410 & 39.0 & 1540 & $38 \cdot 6$ \\
\hline 10 & $\ldots$ & $\ldots$ & 1130 & $38 \cdot 0$ & 1390 & $39 \cdot 0$ & 1590 & $38 \cdot 1$ \\
\hline 11 & $\ldots$ & $\ldots$ & 1080 & $38 \cdot 8$ & 1380 & $39 \cdot 0$ & 1520 & $38 \cdot 6$ \\
\hline 12 & $\ldots$ & $\ldots$ & 1090 & $38 \cdot 3$ & 1400 & $38 \cdot 5$ & 1610 & $38 \cdot 2$ \\
\hline 13 & $\ldots$ & $\ldots$ & 1110 & $\ldots$ & 1460 & $\ldots$ & 1700 & $\ldots$ \\
\hline 14 & $\ldots$ & $\ldots$ & 1180 & $\ldots$ & 1500 & $\cdots$ & 1680 & $\ldots$ \\
\hline 15 & $\ldots$ & $\cdots$ & & $\cdots$ & & $\ldots$ & & \\
\hline 16 & $\ldots$ & $\ldots$ & 1170 & $\ldots$ & 1480 & $\ldots$ & 1720 & $37 \cdot 7$ \\
\hline 17 & $\ldots$ & $\ldots$ & 1220 & ... & 1500 & .. & $\ldots$ & $\ldots$ \\
\hline 18 & ... & $\ldots$ & 1220 & $\ldots$ & 1510 & $\cdots$ & $\cdots$ & $\cdots$ \\
\hline 19 & $\ldots$ & $\ldots$ & $\ldots$ & $\cdots$ & & & $\ldots$ & $\ldots$ \\
\hline 20 & $\cdots$ & $\cdots$ & 1210 & $38 \cdot 7$ & 1570 & $38 \cdot 1$ & $\cdots$ & $\cdots$ \\
\hline 21 & $\cdots$ & $\cdots$ & $\cdots$ & $\cdots$ & $\ldots$ & $\ldots$ & $\cdots$ & $\cdots$ \\
\hline 22 & $\cdots$ & $\cdots$ & 9180 & 38.5 & & $38 \cdot 0$ & $\cdots$ & $\cdots$ \\
\hline 23 & $\cdots$ & $\cdots$ & 1280 & 383 & 1290 & 380 & $\cdots$ & $\cdots$ \\
\hline
\end{tabular}

A number of rabbits were now taken of about the same age, and of 2 kgrms. weight or over, and were treated as follows, in three series:-

Series A, RABbits $1,2,3$ received intraperitoneal injections of one 48 hour old agar culture of typhoid bacilli on seven succeeding days, and at the same time 5 c.c. of antityphoid serum subcutaneously. In the case of rabbits 2 and 3 the injections of serum were continued daily until definite evidence of commencing recovery was apparent.

Series B, RAbBits 1, 2, 3 received intraperitoneal injections of one 48 hour old agar culture of typhoid bacilli on seven succeeding days, and at the same time 5 c.c. of serum extract subcutaneously. In the case of rabbits 2 and 3 the injections of serum extract were continued daily as in Series A.

SERIES C, RABbirs 1-5 received intraperitoneal injections of one 48-hour old agar culture daily until death or until seven injections had been given, whichever occurred the sooner.

The treatment and its results are shown in the accompanying tables.

At the same time Dr. Glücksmann, who had prepared Jez extract in the way described above, undertook parallel observations on the value of this fluid, treating six animals of similar age and weight to mine, three with the same injections of typhoid culture alone and three with these injections, and a daily administration by the mouth of 10 c.c. Jez extract. His results, which he has kindly allowed me to quote, were as follows, the rabbits which received extract being spoken of as "treated," the others as "controls":- 

hours).

After the first injection one treated rabbit died (i.e. within twenty-four

After the second injection two control rabbits died.

After the fifth injection one treated rabbit died.

One control and one treated rabbit survived the seven injections, but were not further observed by Dr. Glücksmann.

In a second series of ten animals, five treated and five controls, all survived the seven injections used, and were observed daily for some weeks without any evidence being obtained either from weight and temperature curves or otherwise of any beneficial effect from the administration of Jez extract.

Turning now to the rabbits used in the observations in Series $A, B$, and $C$, and examining their tables, we note the following points :-

1. Of five controls three died during the period of infection (i.e. 60 per cent.), two after the first injection, and one after the fifth; but of six rabbits treated with serum or serum extract, all survived (i.e. 100 per cent.). The serum and serum extract were therefore strongly protective against the inoculations given.

2. Of the two remaining controls one recovered rapidly and completely; the other died on the twentieth day from first infection with post-mortem signs of an intestinal inflammation after a severe illness, in the course of which its body weight had diminished by some 25 per cent.

3. Of the treated rabbits, those which continued to receive their daily serum or serum extract after the end of the infecting period, namely, 2 and 3 of Series A, and 2 and 3 of Series B (Tables III., IV., VI., and VII.), all recovered completely, though only after serious illness in the case of A 2 and B 2 and 3 . It does not appear from an examination of the tables that the serum extract was in any way superior to ordinary immune serum, for neither was the duration of the illness shorter, nor the percentage loss of weight less, nor the temperature record more favourable with the former than with the latter. And this accords entirely with the results obtained by $\mathrm{Dr}$. Glücksmann with Jez extract. While, therefore, we are by no means in a position to deny the presence of protective substances in the extract, it is clear that such a fluid bears no comparison with the antityphoid serum as a protective agent. The extract being obtained from richly cellular tissues, and especially from those in which the protective bodies are apparently produced, must, without doubt, contain those substances in some degree. But they are probably present only in quite small amounts, in view of the smallness of inmunising injections here employed and the very brief duration of the treatment; and evidently in quantity quite insufficient to perceptibly increase the value of a powerful immune serum, or give protection to inoculated animals.

4. The remaining rabbit of Series B (B 1, Table V.), which received 
serum extract only during the period of infection, became continuously worse, and showed no signs of improvement after seventeen days, at which time it was suddenly attacked by an acute pneumonic process with cough and high pyrexia, which proved fatal on the twentieth day. Besides the chest condition it exhibited post-mortem a serious intestinal inflammation. The rabbit A 1 (Table II.), which received no further serum after the termination of the infecting period, succumbed after a long illness on the thirty-second day, with post-mortem appearances strongly suggestive of true intestinal typhoid, as will be seen immediately.

5. If now we select for consideration those animals which survived the infecting doses, but in which a definite illness was induced, we must except the three controls which died during the period of infection, the rabbit 3, in Series A (Table IV.), in which only moderate and temporary febrile reaction and loss of weight occurred, and No. 2 in Series C (Table IX.), which successfully resisted the infection and rapidly recovered without treatment. That is to say, we have the Rabbits 1 and 2 in Series A, 1, 2, 3 in Series B, and 1 in Series C. Of these six animals three were untreated either throughout the observations (Table VIII.) or from the end of the infective period (Tables II. and V.), and these all died. B 1 (Table V.), however, succumbed eventually to an acute thoracic infection, which set in upon the seventeenth day. It had then already lost 25 per cent. of its original weight and was extremely ill, and would apparently soon have died had the acute infection not arisen. If this animal be omitted from consideration for the present, we still have two untreated animals, namely, $A 1$ and $C 1$, and these both died, while the three treated animals $A 2$ and B 2 and 3 all recovered completely. The number of animals was unfortunately small, but it seems justifiable to conclude, at least provisionally, that the treatment used was definitely curative. And since we have already seen that serum extract had no more favourable an action than serum alone, it is the latter which must be regarded as the curative agent.

6. Again examining the tables of these three animals which died subsequently to the termination of the infecting doses, we observe a time-in B 1 and $\mathrm{C} 1$ on the eleventh day, in A 1 on the fifteenth day - after which the weight of the animal in question ceased to fall or even tended to improve. This was, however, followed quickly by a secondary fall, continuing steadily until the fatal termination of the illness put an end to the observations. After the commencement of the secondary fall A 1 survived about a fortnight, while B 1 and C 1 died at the end of seven days. Now in B 1 and C 1 the post-mortem appearances in the intestine corresponded closely with those usually attributed to the first week of typhoid fever in man; and in $A 1$ to those seen at the end of the second or the beginning of the third week of the same disease. Accordingly it would appear that the 
secondary fall of weight corresponded to the onset of an intestinal typhoid infection; that is to say, to the time at which the infection introduced via the peritoneal cavity developed the condition known as typhoid fever, with its corresponding intestinal signs. The animals treated with serum were therefore cured by it of a disease which otherwise developed into a true intestinal typhoid. In them the stage at which the weight first ceased to fall, was speedily followed under treatment by a period of rapid increase and a general improvement, leading ultimately to complete recovery in from three to six weeks' time.

7. That intestinal typhoid infection can be induced in animals was originally shown by Remlinger. ${ }^{1}$ Chantemesse has also had the like results; and Sanarelli ${ }^{2}$ pointed out that whatever be the method of infection with the $B$. typhosus the small intestine always bears the brunt of the attack. In the animal A 1 appearances were obtained which were conclusive that the animal had suffered from what is usually spoken of as typhoid fever, namely, enlargement of the spleen and abdominal lymphatic glands, numerous small submucous hremorrhages in the stomach, marked enteritis throughout the small intestine, with submucous hremorrhages, and swelling of Peyer's patches, some being hæmorrhagic and a few presenting evidence of ulceration, while in one or two the slough had been already separated. In general behaviour, moreover, the animals conducted themselves in a manner closely similiar to that described by Remlinger in rats, in loss of appetite, in general listlessness, in remaining crouched and motionless in a corner of their cage with closed or half-closed eyes, and in the occurrence of a varying diarrhoea.

The same post-mortem signs as those observed in rabbit $A$, were also accidentally obtained in a guinea-pig which had been infected with the $B$. typhosus, and treated with the antityphoid serum, and which had apparently recovered. This animal a week later was found to be again seriously out of condition with fever and loss of appetite, and ultimately died after about a fortnight. At the autopsy there was acute enteritis, with numerous hæmorrhagic swollen Peyer's patches in the lower part of the small intestine, and the lymphoid plaques of the cæcum, more especially, presented so striking a picture of inflammation, interstitial hiemorrhage and ulceration, that Professor Tavel had the specimen mounted and preserved for demonstration purposes. Two of the Peyer's patches from the rabbit A1 were examined microscopically. They showed marked leucocytic infiltration, with hemorrhages in the deeper layers of the mucosa, and loss of epithelium over the surface of the patches. In the mucosa and the submucosa were numerous bacilli, which lost their stain on using Gram's method.

\footnotetext{
${ }^{3}$ Remlinger, Ann de l'Inst. Pasteur, Paris, 1897, tome xi. 1. 829.

'Sanarelli, Ibid., 1892, tome vi. p. 753.
} 
The conclusions from these observations are as follows :-

1. There is no sufficient evidence that Jez extract prepared from.rabbits has any protective action for these animals against typhoid infection.

2. The antityphoid serum used was both protective and curative to a marked degree.

3. A disease can be produced in animals closely similar to the typhoid fever of man, and the injection of antityphoid serum can prevent the development and fatal termination of this disease in rabbits.

Incidentally to these experiments the agglutinative action of the blood of two of the animals employed was subsequently determined. The observations bear upon the question of the origin of agglutinins. A theory was put forward by Malvoz ${ }^{1}$ that the agglutinins of the blood of immunised animals are neither more nor less than bodies formed in the normal growth of the bacteria in their culture media, and are injected into the animal in the inoculations, and are not produced by a specific reaction of the animal itself. This theory is improbable on various grounds, which have been previously stated by the writer. ${ }^{2}$ Supposing it were true, it would then follow that the serum of an animal which had been injected with certain doses of a typhoid culture only, must be less agglutinative than that of one injected with the same amounts of culture and at the same time also quantities of a highly agglutinative immune serum. Accordingly on the twenty-second day of the experiment the animals $A 3$ and $C 3$ (Tables IV. and X.), which had completely recovered from the treatment, were bled, and serum then prepared. This when tested against the particular B. typhosus in question gave-

For $A 3$, which had received both culture and protective $\{1$ to $30,000+$ serum. . . . . . $\{1$ to 40,000 -

But for C 3, which had only had the typhoid culture $\cdot\left\{\begin{array}{l}1 \text { to } 75,000+ \\ 1 \text { to } 100,000-\end{array}\right.$

That is to say, the serum of the animal which had received culture alone was about twice as agglutinative as that of one which had received both culture and agglutinative serum. The theory of Malvoz is therefore quite untenable, as was indeed sufficiently established by the observations of Deutsch, ${ }^{3}$ and recently also of Moreschi ${ }^{4}$ on the seat of the agglutinin formation; and the production of agglutinins is definitely part of the immunity reaction.

In conclusion, I have again the privilege of offering to Professor Tavel my sincerest thanks, both for the opportunities and advantages of his laboratory and for his personal kindness and encouragement in the course of these experiments.

In the following tables the weights and temperatures were taken daily at about 10 A.M.

1 Ann. de l'Inst. Pasteur, Paris, 1889, tome xiii. p. 635.

${ }^{2}$ Loc. cit.

3 Ibid., 1889, tome xiii. p. 689.

- Boll. a. Soc. med.chir. di Paria, Milano, Fetruary 1901. 
TABLE II.

\begin{tabular}{|c|c|c|c|c|c|c|c|}
\hline \multicolumn{8}{|c|}{ SERIES A.-RABBIT I. } \\
\hline Day. & Weight. & Temperature. & Treatment. & Day. & Weight. & Temperature. & Treatment. \\
\hline 1 & 2400 & $38 \cdot 3$ & $\ldots$ & 17 & 1820 & $39 \cdot 9$ & $\cdots$ \\
\hline 2 & 2450 & $38 \cdot 0$ & ${ }^{*}+$ & 18 & 1830 & $39 \cdot 3$ & $\ldots$ \\
\hline 3 & 2240 & $39 \cdot 2$ & $*+$ & 19 & 1810 & $39 \cdot 4$ & $\cdots$ \\
\hline 4 & 2150 & $39 \cdot 1$ & $*$ & 20 & $\ldots$ & $\ldots$ & $\cdots$ \\
\hline 5 & 2150 & $38 \cdot 3$ & $*$ & 21 & 1810 & $39 \cdot 2$ & $\cdots$ \\
\hline 6 & $\ldots$ & $\ldots$ & $\ldots$ & 22 & 1750 & $38 \cdot 8$ & $\cdots$ \\
\hline 7 & 2080 & $38 \cdot 8$ & $*+$ & 23 & 1750 & $40 \cdot 3$ & $\cdots$ \\
\hline 8 & 2040 & $38 \cdot 7$ & $*$ & 21 & 1760 & $39 \cdot 8$ & $\ldots$ \\
\hline 9 & 2020 & $38 \cdot 7$ & $*+$ & 25 & 1720 & $39 \cdot 3$ & $\cdots$ \\
\hline 10 & 2010 & $38 \cdot 6$ & $\ldots$ & 26 & 1680 & $39 \cdot 0$ & $\cdots$ \\
\hline 11 & 1950 & $38 \cdot 8$ & $\ldots$ & 27 & $\ldots$ & $\ldots$ & $\ldots$ \\
\hline 12 & 1930 & $38 \cdot 6$ & $\ldots$ & 28 & 1640 & $38 \cdot 7$ & $\ldots$ \\
\hline 13 & $\cdots$ & $\cdots$ & $\cdots$ & 29 & 1580 & $39 \cdot 1$ & $\cdots$ \\
\hline 14 & 1820 & $39 \cdot 0$ & $\ldots$ & 30 & 1550 & $39 \cdot 0$ & $\cdots$ \\
\hline 15 & 1790 & $38 \cdot 9$ & $\cdots$ & 31 & 1520 & $38 \cdot 9$ & $\cdots$ \\
\hline 16 & 1850 & $38 \cdot 5$ & $\cdots$ & 32 & 1470 & dead, weighed & after death. \\
\hline \multicolumn{8}{|c|}{ In this and the following experiments- } \\
\hline & & Noo & $\begin{array}{l}=\text { Injection of } \\
=\text { Injection of } \\
=\text { Double dose } \\
\text { servations we }\end{array}$ & $\begin{array}{l}\text { phoid } \\
\text { erum. } \\
\text { if serun } \\
\text { made }\end{array}$ & $\begin{array}{l}\text { Alture. } \\
\text { Sundays. }\end{array}$ & & \\
\hline
\end{tabular}

Post-גIortem.-Thorax.-Nil.

Abdomen.-Spleen large and soft; lymphatic glands enlarged; numerous small subruucous hæmorrhages in the stomach; marked enteritis throughout the small intestine, with submucous hæmorrhages and swelling of Peyer's patches; some Peyer's patches hæmorrhagic, a few with ulceration and erosion, and one or two from which a slough had separated partially or entirely. Peritoneum normal. 
TABLE III.

\begin{tabular}{|r|c|c|c|c|c|c|c|}
\hline \multicolumn{7}{|c|}{ SERIES A. -RABBIT Il. } \\
\hline Day. & Weight. & Temperature. & Treatment. & Day. & Weight. & Temperature. & Treatment. \\
\hline 1 & 2340 & $38 \cdot 3$ & $\ldots$ & 17 & 2280 & $38 \cdot 9$ & + \\
2 & 2360 & $38 \cdot 2$ & $*+$ & 18 & 2300 & $39 \cdot 1$ & $\ldots$ \\
3 & 2340 & $38 \cdot \varepsilon$ & $*+$ & 19 & 2300 & $39 \cdot 0$ & $\ldots$ \\
4 & 2330 & $38 \cdot 9$ & $*+$ & $\ldots$ & $\ldots$ & $\ldots$ & $\ldots$ \\
5 & 2250 & $39 \cdot 8$ & $*+$ & 21 & 2330 & $38 \cdot 6$ & $\ldots$ \\
$\ldots$ & $\ldots$ & $\ldots$ & $\ldots$ & 22 & 2300 & $38 \cdot 7$ & $\ldots$ \\
7 & 2240 & $38 \cdot 9$ & $*+$ & 23 & 2320 & $39 \cdot 1$ & $\ldots$ \\
8 & 2200 & $39 \cdot 4$ & $*$ & 24 & 2340 & $39 \cdot 3$ & $\ldots$ \\
9 & 2170 & $39 \cdot 5$ & $*+$ & 25 & 2360 & $38 \cdot 9$ & $\ldots$ \\
10 & 2030 & $39 \cdot 1$ & + & 26 & 2340 & $39 \cdot 0$ & $\ldots$ \\
11 & 2020 & $38 \cdot 1$ & + & $\ldots$ & $\ldots$ & $\ldots$ & $\ldots$ \\
12 & 2020 & $38 \cdot 3$ & + & 28 & 2330 & $39 \cdot 1$ & $\ldots$ \\
$\ldots$ & $\ldots$ & $\ldots$ & $\ldots$ & 29 & 2280 & $39 \cdot 1$ & $\ldots$ \\
14 & 2100 & $39 \cdot 0$ & + & 30 & 2290 & $38 \cdot 7$ & $\ldots$ \\
15 & 2190 & $39 \cdot 0$ & + & 31 & 2340 & $38 \cdot 4$ & $\ldots$ \\
16 & 2210 & $38 \cdot 9$ & + & 32 & 2400 & $38 \cdot 3$ & $\ldots$ \\
\hline
\end{tabular}

TABLE IV.

\begin{tabular}{|r|c|c|c|c|c|c|c|}
\hline \multicolumn{7}{|c|}{ SERIES A.-RABBIT III. } \\
\hline Day. & weight. & Temperature. & Treatment. & Day. & Weight. & Temperature. & Treatment. \\
\hline 1 & 2160 & $38 \cdot 0$ & $\ldots$ & 12 & 2090 & $38 \cdot 0$ & + \\
2 & 2170 & $38 \cdot 1$ & $*+$ & $\ldots$ & $\ldots$ & $\ldots$ & $\ldots$ \\
3 & 2110 & $38 \cdot 4$ & $*+$ & 14 & 2100 & $38 \cdot 5$ & + \\
4 & 2070 & $38 \cdot 8$ & $*+$ & 15 & 2170 & $38 \cdot 2$ & $\ldots$ \\
5 & 2090 & $39 \cdot 0$ & $*+$ & 16 & 2210 & $38 \cdot 4$ & $\ldots$ \\
$\ldots$ & $\ldots$ & $\ldots$ & $\ldots$ & 17 & 2180 & $38 \cdot 9$ & $\ldots$ \\
7 & 2070 & $38 \cdot 7$ & $*+$ & 18 & 2140 & $38 \cdot 3$ & $\ldots$ \\
8 & 2070 & $39 \cdot 0$ & $*+$ & 19 & 2180 & $38 \cdot 4$ & $\ldots$ \\
9 & 2110 & $39 \cdot 1$ & $*+$ & $\ldots$ & $\ldots$ & $\ldots$ & $\ldots$ \\
10 & 2070 & $39 \cdot 3$ & + & 21 & 2250 & $38 \cdot 4$ & $\ldots$ \\
11 & 2090 & $38 \cdot 8$ & + & 22 & 2270 & $38 \cdot 3$ & bled aud killed. \\
\hline
\end{tabular}

Post-mortem.-Nil. 
TABLE $V$.

\begin{tabular}{|c|c|c|c|c|c|c|c|}
\hline \multicolumn{8}{|c|}{ SERIES B,-RABBIT I. } \\
\hline Day. & Weight. & Temperature. & Treatment. & Day, & Weight. & Temperature. & Treatment. \\
\hline I & 2900 & $38 \cdot 2$ & & 12 & 2240 & $38 \cdot 5$ & $\ldots$ \\
\hline 2 & 2910 & $38 \cdot 1$ & $\dddot{*}+$ & & & & $\cdots$ \\
\hline 3 & 2700 & $40 \cdot 3$ & $*+$ & 24 & 2280 & $38 \cdot 9$ & $\ldots$ \\
\hline 4 & 2540 & 40.7 & *t & 15 & 2230 & $38 \cdot 5$ & $\ldots$ \\
\hline 5 & 2420 & $40 \cdot 0$ & $*+$ & 16 & 2200 & $38 \cdot 9$ & $\ldots$ \\
\hline ... & & & & 17 & 2150 & $38 \cdot 8$ & $\ldots$ \\
\hline$\dddot{z}$ & 2360 & $39 \cdot 1$ & 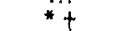 & 18 & 2130 & $40 \cdot 2$ & $\ldots$ \\
\hline 8 & 2340 & $39 \cdot 0$ & $*+$ & 19 & 2060 & $40 \cdot 4$ & $\ldots$ \\
\hline 9 & 2300 & $39 \cdot 1$ & $*+$ & $\ldots$ & & $\ldots$ & $\ldots$ \\
\hline 10 & 2250 & $38 \cdot 4$ & $\ldots$ & 21 & 1930 & dead, weighed & after death. \\
\hline 11 & 2210 & $38 \cdot 7$ & $\ldots$ & $\ldots$ & $\ldots$ & $\ldots$ & $\ldots$ \\
\hline
\end{tabular}

POsT-Montex.-Thorax-Fibrinous pleurisy both sides, with much clear fluid, containing flakes of lymph; broncho-pneumonia throughout both lungs; fibrinous pericarditis.

Abdomen.-Spleen large; lymphatic glands enlarged; small intestine thin and much congested; Peyer's patches swollen and injected.

Table VI.

\begin{tabular}{|c|c|c|c|c|c|c|c|}
\hline \multicolumn{8}{|c|}{ SERIES B.-RABBIT II. } \\
\hline Day. & Weight. & Temperature. & Treatment. & Day. & Weight. & Temperature. & Treatment, \\
\hline 1 & 2330 & $38 \cdot 3$ & & 23 & 1860 & $38 \cdot 8$ & $\ldots$ \\
\hline 2 & 2320 & 38.0 & $*+$ & 24 & 1870 & $38 \cdot 9$ & $\begin{array}{l}\cdots \\
\cdots\end{array}$ \\
\hline 3 & 2130 & $39 \cdot 4$ & $* t$ & 25 & 1920 & $38 \cdot 5$ & $\begin{array}{l}\cdots \\
\cdots\end{array}$ \\
\hline 4 & 1940 & $39 \cdot 4$ & $*+$ & 26 & 1930 & $38 \cdot 6$ & $\cdots$ \\
\hline 5 & 1870 & $38 \cdot 2$ & $* t$ & & & & $\cdots$ \\
\hline & & & & 28 & 1930 & $37 \cdot 9$ & $\ldots$ \\
\hline 7 & 1850 & $38 \cdot 3$ & $*$ & 29 & 1900 & $38 \cdot 5$ & $\ldots$ \\
\hline 8 & 1740 & $36 \cdot 7$ & $*+$ & 30 & 1890 & $38 \cdot 8$ & $\ldots$ \\
\hline 9 & 1710 & $37 \cdot 3$ & $*+t$ & 31 & 1950 & $38 \cdot 2$ & $\cdots$ \\
\hline 10 & 1640 & $38 \cdot 1$ & + & 32 & 2010 & 39.0 & $\ldots$ \\
\hline 11 & 1610 & $38 \cdot 4$ & + & 33 & 2010 & $38 \cdot 8$ & ... \\
\hline 12 & 1610 & $38 \cdot 1$ & + & & & & $\cdots$ \\
\hline$\cdots$ & & & $\cdots$ & 35 & 2090 & $38 \cdot 8$ & $\cdots$ \\
\hline 14 & 1600 & $38 \cdot 4$ & $t$ & 36 & 2160 & $38 \cdot 1$ & $\cdots$ \\
\hline 15 & 1590 & $38 \cdot I$ & $+t$ & 37 & 2180 & $38 \cdot 5$ & $\cdots$ \\
\hline 76 & 1670 & $38 \cdot 9$ & $t$ & 38 & 2200 & $38 \cdot 6$ & $\ldots$ \\
\hline 17 & 1790 & $39 \cdot 0$ & + & 39 & 2200 & $38 \cdot 7$ & $\ldots$ \\
\hline 18 & 1810 & $38 \cdot 9$ & $\ldots$ & 40 & 2290 & $38 \cdot 4$ & $\cdots$ \\
\hline 19 & 1760 & $38 \cdot 5$ & $\cdots$ & & & & $\cdots$ \\
\hline & & & $\cdots$ & 42 & 2340 & $38 \cdot 2$ & $\cdots$ \\
\hline 21 & 1840 & $38 \cdot 7$ & $\ldots$ & 43 & 2350 & $38 \cdot 3$ & $\cdots$ \\
\hline 22 & 1850 & $38 \cdot 9$ & & $\cdots$ & $\ldots$ & $\ldots$ & $\cdots$ \\
\hline
\end{tabular}


TABLE VII.

\begin{tabular}{|c|c|c|c|c|c|c|c|}
\hline \multicolumn{7}{|c|}{ SERIES B. -RABBIT III. } \\
\hline Day. & Weight. & Temperature. & Treatment. & Day. & Weight. & Temperature. & Treatment. \\
\hline 1 & 2320 & $38 \cdot 4$ & $\ldots$ & 17 & 2320 & $39 \cdot 2$ & $\ldots$ \\
2 & 2310 & $38 \cdot 2$ & $*+$ & 18 & 2300 & $39 \cdot 2$ & $\ldots$ \\
3 & 2240 & $39 \cdot 1$ & $*+$ & 19 & 2370 & $39 \cdot 3$ & $\ldots$ \\
4 & 2190 & $40 \cdot 3$ & $*+$ & $\ldots$ & $\ldots$ & $\ldots$ & $\ldots$ \\
5 & 2070 & $39 \cdot 0$ & $*$ & 21 & 2440 & $39 \cdot 1$ & $\ldots$ \\
$\ldots$ & $\ldots$ & $\ldots$ & $\ldots$ & 22 & 2470 & $39 \cdot 1$ & $\ldots$ \\
7 & 2090 & $38 \cdot 6$ & $*$ & 23 & 2400 & $39 \cdot 0$ & $\ldots$ \\
8 & 2100 & $39 \cdot 2$ & $*+$ & 24 & 2440 & $39 \cdot 2$ & $\ldots$ \\
9 & 2150 & $39 \cdot 5$ & $* \dagger$ & 25 & 2360 & $39 \cdot 1$ & $\ldots$ \\
10 & 2150 & $39 \cdot 1$ & $\dagger$ & 26 & 2370 & $39 \cdot 2$ & $\ldots$ \\
11. & 2220 & $39 \cdot 0$ & + & $\ldots$ & $\ldots$ & $\ldots$ & $\ldots$ \\
12 & 2220 & $39 \cdot 0$ & + & 28 & 2300 & $38 \cdot 9$ & $\ldots$ \\
$\ldots$ & $\ldots$ & $\ldots$ & $\ldots$ & 29 & 2350 & $38 \cdot 8$ & $\ldots$ \\
14 & 2300 & $39 \cdot 5$ & $\ldots$ & 30 & 2320 & $38 \cdot 5$ & $\ldots$ \\
15 & 2250 & $39 \cdot 0$ & $\ldots$ & 31 & 2410 & $38 \cdot 6$ & $\ldots$ \\
\hline 16 & 2310 & $39 \cdot 0$ & $\ldots$ & 32 & 2490 & $38 \cdot 4$ & $\ldots$ \\
\hline
\end{tabular}

TABLE VIII.

\begin{tabular}{|c|c|c|c|c|c|c|c|}
\hline \multicolumn{7}{|c|}{ SERIES C.-.RABRIT I. } \\
\hline Vay. & Weight. & Temperature. & Treatment. & Day. & Weight. & Tenuperature. & Treatment. \\
\hline 1 & 2500 & $38 \cdot 4$ & $\ldots$ & 12 & 2240 & $38 \cdot 1$ & $\ldots$ \\
2 & 2550 & $38 \cdot 1$ & $*$ & $\ldots$ & $\ldots$ & $\ldots$ & $\ldots$ \\
3 & 2530 & $38 \cdot 8$ & $*$ & 14 & 2320 & $38 \cdot 3$ & $\ldots$ \\
4 & 2440 & $38 \cdot 7$ & $*$ & 15 & 2320 & $38 \cdot 2$ & $\ldots$ \\
5 & 2370 & $38 \cdot 8$ & $*$ & 16 & 2310 & $38 \cdot 0$ & $\ldots$ \\
$\ldots$ & $\ldots$ & $\ldots$ & $\ldots$ & 17 & 2300 & $38 \cdot 5$ & $\ldots$ \\
7 & 2270 & $38 \cdot 8$ & $*$ & 18 & 2250 & $38 \cdot 7$ & $\ldots$ \\
8 & 2240 & $38 \cdot 7$ & $*$ & 19 & 2210 & $38 \cdot 8$ & $\ldots$ \\
9 & 2200 & $38 \cdot 5$ & $*$ & $\ldots$ & $\ldots$ & $\ldots$ & $\ldots$ \\
10 & 2210 & $38 \cdot 5$ & $\ldots$ & 21 & 2090 & dead, xeighed after death. \\
\hline 12 & 2180 & $38 \cdot 0$ & $\ldots$ & $\ldots$ & $\ldots$ & $\ldots$ & $\ldots$ \\
\hline
\end{tabular}

Post-Mortem.-Thorax.-Nil.

Abdomen.--Spleen large; abdominal glands enlarged, and one mesenteric gland full of thick creamy pus; acnte enteritis throughout the small intestine; Peyer's patches swollen and injected. 
TABLE IX.

\begin{tabular}{|c|c|c|c|c|c|c|c|}
\hline \multicolumn{8}{|c|}{ SERIES C.-RABBIT II. } \\
\hline Day. & Weight. & Temperature. & Treatment. & Day. & Weight. & Temperature. & Treatment. \\
\hline $\begin{array}{l}1 \\
2 \\
3 \\
4\end{array}$ & $\begin{array}{l}2750 \\
2790 \\
2700 \\
2520\end{array}$ & $\begin{array}{l}38 \cdot 0 \\
38 \cdot 1 \\
39 \cdot 3 \\
39 \cdot 1\end{array}$ & $\begin{array}{l}\because \\
*\end{array}$ & $\begin{array}{r}5 \\
\cdots \\
7 \\
8\end{array}$ & $\begin{array}{c}2360 \\
\ldots \\
2240 \\
2180\end{array}$ & $\begin{array}{c}40.2 \\
\ldots \\
39.8 \\
\text { dead, weighed }\end{array}$ & $\begin{array}{c}* \\
\ldots \\
* \\
\text { after death. }\end{array}$ \\
\hline
\end{tabular}

TABLE $\mathrm{X}$.

\begin{tabular}{|c|c|c|c|c|c|c|c|}
\hline \multicolumn{8}{|c|}{ SERIES C. -RABBIT III. } \\
\hline Day. & Weight. & Temperature. & Treatment. & Day. & Weight. & Temperature. & Treatment. \\
\hline 1 & 2000 & $38 \cdot 0$ & & 12 & 1990 & $37 \cdot 5$ & $\ldots$ \\
\hline$\hat{2}$ & 2060 & $38 \cdot 1$ & $\because$ & 20 & & & $\ldots$ \\
\hline 3 & 2050 & $38 \cdot 8$ & * & 14 & 2030 & $38 \cdot 2$ & $\ldots$ \\
\hline 4 & 2010 & $38 \cdot 4$ & * & 15 & 2030 & $38 \cdot 0$ & $\ldots$ \\
\hline 5 & 2010 & 38.3 & * & 16 & 2080 & $37 \cdot 7$ & $\ldots$ \\
\hline & & & & 17 & 2100 & $38 \cdot 0$ & $\ldots$ \\
\hline 7 & 2050 & $38 \cdot 4$ & * & 18 & 2080 & $38 \cdot 4$ & $\ldots$ \\
\hline 8 & 2070 & $38 \cdot 4$ & $*$ & 19 & 2080 & $38 \cdot 5$ & $\ldots$ \\
\hline 9 & 1990 & $38 \cdot 2$ & * & & & $\ldots$ & $\ldots$ \\
\hline 10 & 1920 & $38 \cdot 1$ & $\ldots$ & 21 & 2140 & $38 \cdot 4$ & $\ldots$ \\
\hline 11 & 1910 & $38 \cdot 3$ & $\ldots$ & 22 & 2150 & $38 \cdot 3$ & bled and klled. \\
\hline
\end{tabular}

Post-mortem.-Nil.

TABISE XI.

\begin{tabular}{|c|c|c|c|}
\hline \multicolumn{3}{|c|}{ SERIES C.-RABBIT IV. } \\
\hline Day. & Weight. & Temperature. & Treatment. \\
\hline & & & \\
\hline 1 & 2360 & $38 \cdot 5$ & $\ldots$ \\
2 & 2410 & $38 \cdot 3$ & * $^{*}$ \\
3 & 2330 & dead, weighed after death. \\
\hline
\end{tabular}

TABLE XII.

\begin{tabular}{|c|c|c|c|}
\hline \multicolumn{4}{|c|}{ SERIES C.-RABBIT V. } \\
\hline Day. & Weight. & Temperature. & Treatment. \\
\hline $\begin{array}{l}1 \\
2 \\
3\end{array}$ & $\begin{array}{l}2030 \\
2000 \\
1950\end{array}$ & $\begin{array}{c}38 \cdot 7 \\
38 \cdot 0 \\
\text { dead, weig }\end{array}$ & $\begin{array}{c}\dddot{*} \\
\text { after death. }\end{array}$ \\
\hline
\end{tabular}

